Paedagogia Christiana

2/30 (2012) - ISSN 1505-6872

Kazimiera J. Wawrzynów*

Wrocław

\title{
Nauczyciel partycypującym liderem. TZI jako model nauczania i wychowania według Ruth C. Cohn
}

\section{Wprowadzenie}

Literatura pedagogiczna coraz więcej uwagi poświęca nauczycielowi, jego osobie i profesjonalizmowi. Przedmiotem badań są oczekiwania wobec nauczyciela i stawiane mu wymagania. Szuka się nowych sposobów wspierania go w procesie wprowadzania niezbędnych zmian i przewartościowań $\mathrm{w}$ jego poglądach pedagogicznych i w próbach odpowiadania na aktualne wyzwania społeczno-kulturowe ${ }^{1}$.

W niniejszym artykule koncentrujemy się na wpływie interpersonalnych relacji nauczyciela z uczniami na efekty procesu dydaktyczno-wychowawczego i pytamy: Czy współczesny nauczyciel może być autorytetem odpowiedzialnym za proces dydaktyczny i jego rezultaty, a zarazem uczestnikiem tego procesu w klasie szkolnej? Na to pytanie udziela odpowiedzi Ruth Charlotte Cohn w swoim modelu interakcji skoncentrowanej na temacie

* S. dr Kazimiera J. Wawrzynów OSU jest adiunktem w Katedrze Teologii Pastoralnej Papieskiego Wydziału Teologicznego we Wrocławiu.

${ }^{1}$ Por. np.: Z. Bartkowicz, Nauczyciel kompetentny w perspektywie deontologicznej, w: Z. Bartkowicz, M. Kowaluk, M. Samujło (red.), Nauczyciel kompetentny. Teraźniejszość i przyszłość, Lublin 2007, s. 28-31. 
(Themenzentrierte Interaktion, dalej: TZI) ${ }^{2}$. Po krótkim zapoznaniu z historią życia R.C. Cohn i jej koncepcją przedstawię wynikający z niej szczególny wymiar partycypującego liderstwa nauczyciela.

TZI jest integralnym systemem pedagogicznym. Opiera się na założeniu, że im bardziej zadanie lub treści uczenia się, interakcje członków grupy i rozwój poszczególnych osób są ze sobą wzajemnie powiązane i traktowane jako równowartościowe, tym bardziej współpraca jest skuteczna. Relacje zewnętrzne, środowisko, procesy społeczno-polityczne oddziałują nań zawsze w sposób otwarty lub ukryty. One wywierają wpływ i mogą także podlegać wpływom. TZI, choć bywa stosunkowo często określana jako „metoda”, jest przede wszystkim postawą zorientowaną na wartości z wynikającymi z niej dydaktyczno-metodycznymi konsekwencjami dotyczącymi planowania i kierowania procesami nauczania i uczenia się ${ }^{4}$ W takim znaczeniu TZI znalazła zastosowanie między innymi także w edukacji szkolnej.

\section{Podstawy interakcji skoncentrowanej na temacie}

Interakcja skoncentrowana na temacie (TZI) jest postawą i metodą zorientowaną na wartości, która znajduje swój wyraz zwłaszcza w pedagogiczno-terapeutycznych procesach grupowych mających znaczenie społeczne.

\subsection{Droga życiowa Ruth C. Cohn}

Powstanie i podstawy TZI łączą się ściśle z historią życia R. C. Cohn (1912-2010), która jest wybitną przedstawicielką psychologii humanistycznej. Z wykształcenia psychoanalityk pracowała trzydzieści lat nad tym, by wprowadzić elementy pedagogiczno-terapeutyczne do nauczania i innych grup komunikacyjnych ${ }^{5}$. Znaczący wpływ na nią miało doświadczenie przemocy narodowego socjalizmu. Jako Żydówka musiała emigrować z Berlina,

2 Odtąd dla Themenzentrierte Interaktion używamy skrótu TZI.

${ }^{3}$ Por. R. C. Cohn, Themenzentrierte Interaktion. Kein „, Regelsystem”, keine ,, leiterlose Gruppe”, „Wege zum Menschen” 27 (1975), s. 486-489; tenże, Über den ganzheitlichen Ansatz der Themenzentrierten Interaktion, „Integrative Therapie” 5 (1979), s. 252-258; D. Stollberg, Lernen, weil es Freude macht. Eine Einführung in die Themenzentrierte Interaktion, München 1982, s. 43.

${ }^{4}$ Por. S. Hagleitner, Mit Lust an der Welt - in Sorge um sie. Feministisch-politische Bildungsarbeit nach Paolo Freire und Ruth C. Cohn, Mainz 1996.

5 R. C. Cohn, Von der Psychoanalyse zur Themenzentrierten Interaktion. Von der Behandlung einzelner zu einer Pädagogik für alle, Stuttgart 1992, s. 7. 
gdzie studiowała ekonomię narodową, najpierw do Szwajcarii, a potem do Stanów Zjednoczonych. Podczas pobytu w Zurychu przez sześć lat zajmowała się analizą nauczania, do wyników której nabrała potem krytycznego dystansu. W USA (1941) poznała nowe wtedy formy terapii, które obok psychoanalizy, terapii ciała i holistycznej zasady biopsychologicznej jedności człowieka jako części uniwersalnej całości miały znaczący wpływ na jej koncepcje.

Za miejsce narodzin TZI uważa się warsztat przeniesienia w grupach kierowany przez Ruth C. Cohn w 1955 roku. Przedstawiła wtedy swoją koncepcję w sposób symboliczny, jako równoramienną piramidę z czterema wierzchołkami, które interpretowała jako podstawę każdego procesu komunikacji grupowej:

1. JA (indywidualna osoba) - świadoma samej siebie, zwraca się do innych i do tematu w pewnej określonej sytuacji grupowej;

2. MY (grupa) - reprezentuje wzajemny stosunek poszczególnych osób i stosunek do tematu w ich interakcji;

3. TO (zadanie lub temat) - stanowi ważną sprawę do opracowania zespołowego;

4. GLOBE (kontekst życiowy, środowisko) - wpływa na grupę w wewnętrznych relacjach wzajemnych jej członków oraz na jej pracę w sensie ścisłym i szerszym.

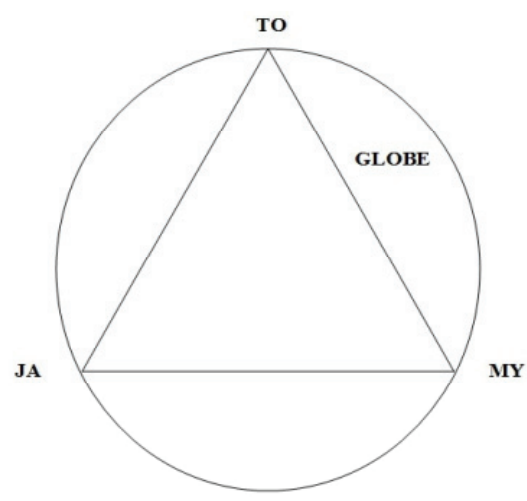

Prowadzenie grup według TZI charakteryzuje harmonijność i „dynamiczna równowaga" między JA, MY, TO i GLOBE. W późniejszym doprecyzowaniu podstawy pracy został wpisany temat - mówiąc obrazowo w centrum piramidy. $Z$ właściwie sformułowanego tematu, który staje się „fokusem” procesu grupowego, wyprowadzane są formy pracy, metody i środki. 


\subsection{Podstawy antropologiczno-etyczne}

Wbrew próbom redukowania TZI do metody kierowania procesami grupowymi R.C. Cohn podkreśla, że nierozdzielne w nim są ,humanistyczna solidarność i duchowe odniesienie do wartości połączone ze specyficznym założeniem metodycznym"6. Związek TZI z wartościami najwyraźniej wyraża się w ,aksjomatach”, które są niededukowalnymi założeniami ${ }^{7}$.

1. Pierwszy aksjomat wyraża antropologię Cohn. Jego fundamentem jest integralna koncepcja człowieka rozumiana w taki sposób, że osoba jako taka stanowi indywiduum, a zarazem część środowiska, i to tworzy całość. Odnosi się ona do odczuwania, myślenia i działania. Twórczyni koncepcji, uznając autonomię człowieka, wymaga zarazem, by był odpowiedzialny za świat, jego przemiany oraz jego historię. Tak brzmi aksjomat antropologiczny: „Człowiek jest psychobiologiczną jednością i częścią uniwersum. Dlatego jest on zarazem autonomiczny i zależny. Ten, kto jest świadom swojej współzależności wobec wszystkich i wszystkiego, posiada większą autonomię".

2. W aksjomacie etycznym Cohn mówi o sensie i wartości ludzkiego życia i działania: „Głęboki szacunek należy się każdej istocie żyjącej i jej rozwojowi. Respekt wobec rozwoju warunkuje wartościującą decyzję. To, co ludzkie, jest wartościowe, a to, co nieludzkie, niehumanitarne, zagraża wartościom" ". Aksjomat etyczny uzupełniła ona swoją hipotezą „wrodzonego", „organicznego sensu wartości”, który jest potrzebny do rozwinięcia problemu przeżycia ludzkości ${ }^{10}$.

3. Aksjomat pragmatyczno-polityczny łączy to, co wewnętrzne, z tym, co zewnętrzne, oraz wszystkie trzy aksjomaty z sobą: „Wolna decyzja dokonuje się w uwarunkowanych granicach wewnętrznych i zewnętrznych. Rozszerzenie tych granic jest możliwe. Przestrzeń naszej wolności jest większa wtedy, gdy jesteśmy zdrowi, inteligentni, materialnie zabezpieczeni i psychicznie dojrzali, niż gdy chorujemy, jesteśmy ograniczeni lub ubodzy, czy cierpimy z powodu przemocy i braku dojrzałości. Świadomość uniwersalnej zależności jest podstawą ludzkiej odpowiedzialności”"11. Człowiek postępuje

6 Tenże, Über den ganzheitlichen Ansatz, s. 253.

7 Tenże, Zur Grundlage des themenzentrierten interaktionellen Systems: Axiome, Postulate, Hilfsregeln, „Gruppendynamik” 3 (1974), s. 150.

${ }^{8}$ R. C. Cohn, A. Farau, Gelebte Geschichte der Psychotherapie. Zwei Perspektiven, Stuttgart 1993, s. 357.

9 Tamże, s. 358.

10 Tamże, s. 467-484.

${ }^{11}$ R. C. Cohn, Von der Psychoanalyse, s. 120. 
więc odpowiedzialnie po ludzku właśnie wtedy, gdy jest świadom uniwersalnego uwarunkowania wolności i wykorzystuje swoją przestrzeń wolności wewnątrz GLOBE.

Obok tych aksjomatów TZI przedstawia także postulaty i reguły pomocnicze. Postulaty są miejscem styku aksjomatów i metodyki TZI. Cohn opisuje dwa postulaty egzystencjalne: postulat zarządzania (chairperson Postulat) oraz tak zwany postulat pierwszeństwa przeszkód (Störungs-Prioritäts-Postulat).

Postulat chairperson w sformułowaniu: „Bądź swoim własnym prezesem" zawiera podwójny akcent; z jednej strony chodzi tu o odpowiedzialność wobec siebie samego i swego wewnętrznego świata, z drugiej zaś strony o poczucie odpowiedzialności wobec środowiska. Postulat pierwszeństwa przeszkód brzmi: „Problemy i konsternacje mają pierwszeństwo" w nim o postrzeganie rzeczywistości z jej problemami i wyzwaniami, które nie pytają o pozwolenie, lecz po prostu są.

\section{Partycypujący styl kierowania}

TZI jest modelem żywego uczenia się i komunikacji, dynamiczną strukturą, której różne części łączą się wzajemnie. Teraz spróbuję naszkicować jeden z istotnych faktorów TZI w kontekście szkolnego procesu nauczania i uczenia się, jakim jest postać nauczyciela - partycypującego lidera. W tym celu przedstawię najpierw pojęcie partycypującego uczestnictwa TZI i jego pochodzenie, a następnie ukażę postać nauczyciela, jako uczestniczącego lidera w procesie kształcenia szkolnego.

\subsection{Definicja}

Partycypujące liderstwo (PL) określa koncepcję przewodnictwa TZI, która powinna służyć refleksji, diagnozie i kierowaniu procesami uczenia się i pracy grup, zespołów i organizacji. Kompleksowość zadania liderstwa, według TZI, jasno wyraża się w obydwu pojęciach, zarówno w przewodniczeniu, jak i w uczestnictwie.

R.C. Cohn wyjaśnia: „Liderzy grup są jednakże w pierwszej linii uczestnikami, a więc osobami z własnymi zainteresowaniami, upodobaniami, myślami i uczuciami, a dopiero w drugiej kolejności zajmują specjalną pozycję jako kierownicy grup. Pełnienie tej funkcji polega wpierw na tym,

${ }^{12}$ R. C. Cohn, A. Farau, dz. cyt., s. 360. 
by uwzględniać dynamiczną równowagę między JA-MY-TO oraz środowiskiem (GLOBE)"'13.

W koncepcję partycypującego kierowania wpisana jest zasadnicza dialektyczna struktura myślowa, która prowadzi ciągle na nowo do syntezy abstynencji i uczestnictwa ${ }^{14}$. Wymaga to zatem od lidera postrzegania swojego świadomego i nieświadomego działania i reagowania tak na uczestników, jak i na całość procesów. Nauczyciel więc postrzega, a przez to selektywnie, autentycznie utrzymuje proces uczenia się $\mathrm{w}$ równowadze między diagnostycznym dystansem a osobistym współprzeżywaniem.

Od początku interakcji skoncentrowanej na temacie (TZI) partycypujące liderstwo jest ideą ważną ${ }^{15}$. Pojęcie zostało opisane przez Cohn raczej jako orientacja kierująca działaniem liderów. Zastosowanie selektywnej autentyczności (selektiver Authentizität) ma tu centralne znaczenie. Matzdorf i Cohn w następujący sposób ujmują aspekty PL: „Liderstwo jest rozumiane jako kierowanie sobą i grupa (Sich-selbst-und-die-Gruppe-Leiten)”; „Kierujący są partycypującymi członkami grupy ponoszącymi odpowiedzialność za: strukturę, dynamiczną równowage procesu i zwracanie uwagi na poszczególne osoby oraz ich potrzeby”; „funkcjonalne kierowanie grupa nie jest zorientowane na status”; ,usuwanie autorytarnych i antyautorytarnych postaw (selektywna autentyczność, troska o adekwatną komunikację, podział funkcji i przejrzystość w demokratycznej współpracy z grupa)”16.

\subsection{Pochodzenie}

Pojęcie uczestniczącego kierownictwa pojawia się w koncepcji Cohn dosyć wcześnie jako konsekwencja ewolucji pojęcia psychoanalitycznej praktyki wstrzemięźliwości terapeuty ${ }^{17}$. Selektywność zakłada abstynencję, a wymóg aktywnego uczestnictwa w problemie klienta ją ogranicza. $\mathrm{Z}$ terapii przeżyciowych Cohn przejmuje ,zasadę partnerstwa uczestniczącego lidera" jako jedną z pięciu zasad, które charakteryzują terapie przeżycio-

13 Tamże, s. 368.

${ }^{14}$ H. Reiser, TZI als pädagogisches System, w: H. Reiser, W. Lotz (red.), Themenzentrierte Interaktion als Pädagogik, Mainz 1995, s. 16-21.

${ }_{15}$ H. Reiser, A. Dlugosch, Einführung in die Themenzentrierte Interaktion, Hagen 1997, s. 26.

${ }^{16}$ P. Matzdorf, R. C. Cohn, Das Konzept der Themenzentrierten Interaktion, w: C. Löhmer, R. Standhardt (red.), TZI. Pädagogisch-therapeutische Gruppenarbeit nach R.C. Cohn, Stuttgart 1992, s. 91.

${ }^{17}$ R. C. Cohn, Von der Psychoanalyse, s. 97. 
$w^{18}{ }^{18}$ „,Wspólne dla nich jest to, że terapeuta lub nauczyciel działa nie jako «neutralny» lub dyrygujący kierownik, lecz jako uczestnik, wnoszący samego siebie jako osobę"19. Jako kierownik warsztatu przeciwprzeniesienia, działającego w ramach kształcenia psychoanalityków, R.C. Cohn podejmuje nietypową decyzję włączenia się w grupę jako jej członkini i uczestniczka. Krok ten zdecydowanie wpłynął na rozwój rozumienia liderstwa TZI:

Nauczyciel jest pomocnikiem pedagogiczno-terapeutycznym i katalizatorem, jeśli jest on prawdziwy i kongruentny w swoich wypowiedziach. [...] Jako lider i jako uczestnik jestem jak wy: ale ja jestem prowadzącym. Jestem chairman mnie samego i chairman grupy. Jako chairman grupy traktuję siebie jako instrument, niezależnie od tego, jak ja sama się czuję. Moja odpowiedzialność polega na tym, by nie wycofywać się z funkcji kierowania sobą i grupą i odpowiedzialności za temat. Ja czuję, myślę, jestem niespokojna, jestem opanowana, apatyczna lub zapalona niezależnie od tego, jak się czuję. Nie chcę pomijać samej siebie i pragnę zwrócić się do was oraz reprezentować temat. Jestem dla was optymalnie (nie maksymalnie!) transparentna ${ }^{20}$.

„Selektywna autentyczność” służy wspieraniu zaufania i zrozumienia. „Komunikacja interpersonalna wymaga taktu i wyczucia (timing). Otwartość bez selektywności może szkodzić" 21.

\subsection{Recepcja}

W recepcji należy rozróżnić dwie płaszczyzny: ideologiczną oraz uzasadnienia pedagogicznego z wdrożeniem. Najpierw zajmiemy się aspektem ideologicznym.

\section{Plaszczyzna ideologiczna}

Dla Cohn ${ }^{22}$ zniesienie hierarchicznej pozycji przewodnika ma znaczenie społeczne, przez co osiaga ona zamierzony cel. Zadaniem lidera jest przyjęcie koniecznej funkcji kierowniczej, objęcie władzy należącej do niej i jed-

18 P. Matzdorf, R. C. Cohn, dz. cyt., s. 43.

19 R. C. Cohn, Von der Psychoanalyse, s. 97.

20 Tamże, s. $188 \mathrm{n}$.

${ }^{21}$ P. Matzdorf, R. C. Cohn, dz. cyt., s. 77.

${ }^{22}$ A. Ockel, R. C. Cohn, Das Konzept des Widerstands in der Themenzentrierten Interaktion, w: C. Löhmer, R. Standhardt (red.), dz. cyt., s. 198. 
noczesne uczestniczenie w procesie. H. Reiser nazywa to „demokratycznym kierownictwem funkcjonalnym"23. Kryterium powodzenia sformułowane przez Reisera ${ }^{24}$ polega na tym, że interwencje kierownika powinny dążyć do zniesienia pozycji swojej władzy, aby w ten sposób relatywizować przeniesienie na prowadzącego. Postuluje on także drugie kryterium mówiące, że miara selektywności i autentyczności różnych środowisk społecznych, na przykład: szkół, przedsiębiorstw, polityki, musi być odpowiednia i z nimi uzgodniona ${ }^{25}$.

\section{Plaszczyzna pedagogiczna}

Istnieje wiele konkretnych sposobów pedagogicznego kształtowania uczestniczącego przewodzenia. Wskazują one, jakie umiejętności są tu potrzebne. Również B. Langmaack ${ }^{26}$ jest zdania, że kierownik jako modelowy uczestnik, przez wypowiedzi o sobie samym, wspiera zaufanie, a to z kolei ma dobry wpływ na procesy dynamiki uczenia się i dynamiki grupowej. Ideę, którą kieruje się Cohn, można sformułować następująco: „Wszystko, co mówię, powinno być prawdziwe, ale nie wszystko, co jest prawdziwe, powinienem powiedzieć" ${ }^{27}$. Odpowiednie dla TZI podejście do fenomenów przeniesień wymaga w kontekście partycypującego uczestnictwa określonych umiejętności. Inaczej jest w klasycznej psychoanalizie, która koncentruje się na przeniesieniu, aby je przepracować. Liderzy TZI kładą akcent na staranne i jednoznaczne przeciwstawienie i opracowanie każdego przeniesienia, aby osiagnąć relacje międzyosobowe zbliżone do tych, które istnieja w rzeczywistości. H. Reiser ${ }^{28}$ i H. Raguse ${ }^{29}$ są zdania, że model ten wymaga szczególnej - prawie niemożliwej i paradoksalnej - umiejętności zanurzenia się w proces i równoczesnego ponownego zdystansowania się do niego. Mówiąc psychoanalitycznie, chodzi o równoczesne występowanie wstrzemięźliwości i empatycznego uczestnictwa. Raguse ${ }^{30}$ uważa za najważniejszy warunek to, aby liderzy nie lękali się o samych siebie, krytyki uczestników

${ }^{23}$ H. Reiser, dz. cyt., s. 16-21.

${ }^{24}$ H. Reiser, A. Dlugosch, dz. cyt., s. 26.

${ }^{25}$ H. Reiser, dz. cyt., s. 27.

${ }^{26}$ B. Langmaack, Einführung in die Themenzentrierte Interaktion TZI. Leben rund ums Dreieck, Weinheim 2001, s. 200.

27 R.C. Cohn, A. Farau, dz. cyt., s. 371.

${ }^{28}$ H. Reiser, A. Dlugosch, dz. cyt., s. 27.

${ }^{29}$ H. Raguse, Aggression und Destruktion in der Arbeit mit TZI-Gruppen, w: R. Abeln (red.), Aggression in Gruppen, Mainz 1994, s. 146.

${ }^{30}$ Tenże, Vermiedene Themen in Gruppen am Beispiel der TZI, „Praxis Spiel und Gruppe 2" 3 (1992), s. 92-96. 
swoich grup, a także poruszania drażliwych tematów, to znaczy nie unikali ich. „Stąd każdy kierownik grupy TZI musi znaleźć drogi uczenia się rozumienia siebie [...] w swoich wzorcach relacji. Liderzy grup TZI pracuja efektywniej, gdy ciagle poszerzają osobiste horyzonty znajomości siebie i drugiego człowieka".

Podsumowując można przeciwstawić sobie dwie koncepcje. Pierwsza z nich mówi, że kierowanie połączone z uczestnictwem jest tak trudne, że aż niemożliwe. B. Lemaire ${ }^{31}$ uważa, że przez partycypujące kierownictwo sami doprowadzamy do osłabienia autorytetu i władzy osób kierujących, wprowadzając niejasność, przez co odbiera się uczestnikowi możliwość lub konieczność ustosunkowania się do tego autorytetu. Argumentacja K.W. Vopela ${ }^{32}$ streszcza się w następującym stwierdzeniu: „Lider TZI musi pracować pseudopartycypatywnie. [...] Jest on obrońcą i realizatorem tematu, który sam podał". Tutaj jednak niewystarczająco byłyby uwzględnione realne różnice wpływów. Jednakże Vopel redukuje partycypujące liderstwo do uczestniczącego kierowania, które przedstawia tylko jeden jego aspekt, a przemilcza to, że lider TZI ma także zadanie tematyzowania i omawiania różnych układów sił. Podsumowując krytykę koncepcji partycypującego lidera, zauważa więc, że mami ona równością, a różnice tuszuje, utrudnia dyskusję z kierownictwem, podważa władzę i autorytet. Lider może odwracać uwagę od uczestników, chociaż to o nich chodzi w procesie uczenia się, o ich rozwój i pracę.

Natomiast R. Hintner, Th. Middelkoop oraz J. Wolf-Hollander ${ }^{33}$ reprezentują tezę, że nie jest możliwe owocne kierowanie bez postawy uczestnictwa. W literaturze często przewijają się sugestie mówiące, że przez aktywne otwarcie się na grupę proces grupowy staje się kompasem dla lidera. Jego wczucie się i zaangażowanie rodzi pewność następnych kroków rozwoju grupowego. Zdaniem tych autorów rozumienie kierownictwa wyraża się przez interwencje w grupie ${ }^{34}$. Specyficzne dla TZI partycypujące liderstwo oznacza świadome, selektywnie-autentyczne kształtowanie uczestniczenia na bazie równowagi między diagnostycznym dystansem i osobistym współprzeżywaniem. Zdaniem R. Hintner, literatura przedmiotu przeważnie anali-

31 B. Lemaire, Partizipierend Leiten - wem oder was nützt der vorprogrammierte Rollenkonflikt, w: K. Hahn, M. Schraut (red.), Kompetente Leiterinnen. Beiträge zum Leitungsverständnis nach TZI, Mainz 2001, s. 118-139.

32 K. W. Vopel, Ein Update für die TZI, ,Themenzentrierte Interaktion” 14 (2000), s. 82.

33 Por. R. Hintner, Th. Middelkoop, J. Wolf-Hollander, Partizipierend Leiten, w: J. Spielmann, M. Schneider-Landolf, W. Zitterbarth (red.), Handbuch themenzentrierte Interaktion (tzi), Göttingen 2009, s. 188.

34 Por. R. Lang-Körsgen, Veränderungen im TZI Leitungsverständnis durch gesellschaftspolitische Veränderungen, w: K. Hahn, M. Schraut (red.), dz. cyt., s. 11. 
zuje poszczególne aspekty, przez co nie daje całościowego obrazu partycypującego uczestnictwa.

\section{Partycypujący styl kierowania w pracy nauczyciela}

\subsection{Uwagi wprowadzające}

Ruth C. Cohn wprowadza w rozumienie zadania nauczyciela w systemie TZI tak pisząc: „Jako lider jestem uczestnikiem, podobnie jak wy, ale ja jestem prowadzącym. Jestem przewodniczącym (chairman) mnie samego i chairman grupy"35. TZI jest więc modelem kierowania sobą samym i zespołem osób ${ }^{36}$. Liderzy w tym systemie są przede wszystkim uczestnikami. Jako równoprawni współczłonkowie wnoszą oni w proces grupowy także pewne osobiste idee i zainteresowania. Dopiero w drugiej kolejności przewodnicy grup TZI pełnią specjalną funkcję. B. Langmaack przedstawia tę funkcję w postaci tak zwanej sześciokrotnej uwagi ${ }^{37}$.

Przewodniczenie w ujęciu TZI oznacza, że lider w procesie grupowym jest także uczestnikiem, który z sześciokrotną uwagą postrzega kompleksowy bieg wydarzeń i postępuje adekwatnie do niego. Uczestniczące przewodniczenie nauczyciela wymaga stałego ćwiczenia i ciagle nowego opowiadania się za konkretnym procesem pracy. W rozwijaniu takiej postawy mogłyby pomóc nauczycielowi następujące pytania: Jakie aspekty pracy ma pani/pan na uwadze, a jakie giną z pola postrzegania? W jakich okolicznościach traci je pan/pani z oczu?

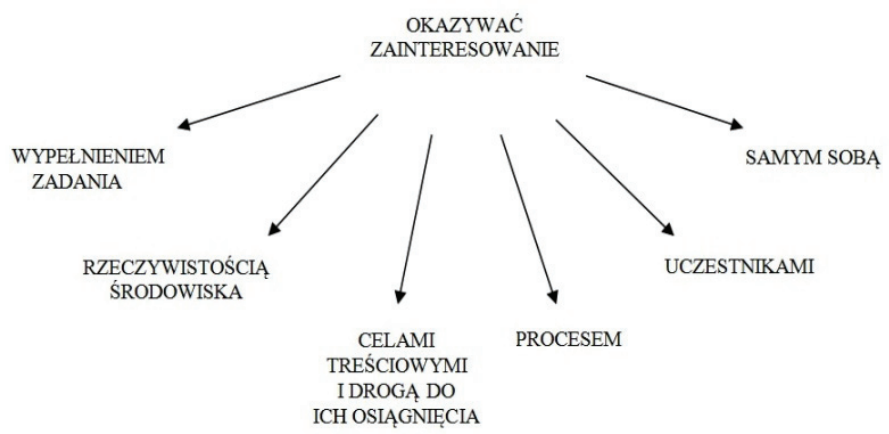

${ }^{35}$ R. C. Cohn, Von der Psychoanalyse, s. 189.

36 Por. P. Matzdorf, R. C. Cohn, dz. cyt., s. 83.

37 B. Langmaack, dz. cyt., s. 128. 
Tak zwana sześciokrotna uwaga uwzględnia następujące wymiary procesu dydaktycznego ${ }^{38}$ :

1. cele i uzgodnienia, które zostały omówione z grupa, i odpowiadają założeniom programu nauczania;

2. możliwości lub ograniczenia płynące z GLOBE (np. szkoła);

3. konkretne cele treściowe i aktywne współkształtowanie grupy w procesie ich realizacji;

4. dynamikę grupy, do której należą początkowe trudności, etapy pracy z towarzyszącymi produktywnymi kryzysami i ciągle na nowo określanie miejsca, w jakim się znajdujemy;

5. poszczególnych uczestników, którzy zawsze idą indywidualnymi drogami uczenia się;

6. siebie samego z własnymi możliwościami i ograniczeniami, szczególnymi upodobaniami, niechęcią, rozczarowaniami, nadziejami i potrzebami.

Tak przedstawiona „sześciokrotna uwaga” jest charakterystyczna dla koncepcji przewodnictwa TZI. Może być jednak uzupełniana przez dalsze elementy ${ }^{39}$. Ważne jest, by starać się przede wszystkim o zachowanie dynamicznej równowagi między zainteresowaniami poszczególnych osób tworzących grupę a zadaniem w jego relacji ze środowiskiem. Jeśli bowiem nikt nie jest odpowiedzialny za dynamiczną równowagę, dochodzi albo do utraty właściwego procesu komunikacji między członkami grupy w klasie szkolnej, albo do zagubienia tematu.

Nauczyciel pełni rolę aktywnego pomocnika w uczeniu się i pracy przez proponowane tematy, struktury uczenia się i interwencje wspiera grupę w rozwoju i równocześnie animuje ją w procesie realizacji zadania ${ }^{40}$. Lider jest więc uczestnikiem ze szczególnymi, jasno zarysowanymi zadaniami. Cohn porównuje jego zadanie z pozycją pierwszego skrzypka ${ }^{41} \mathrm{w}$ orkiestrze, który również pełni podwójną funkcję, bo gra swoją część partytury, zwracając jednocześnie ciągle uwagę na innych i wspólną grę. Tak i tu przewodnictwo TZI należy rozumieć jako partycypujące, ujmując to w krótką formułę: partycypujący styl kierowania ${ }^{42}$.

\footnotetext{
38 Por. tamże, s. $127 \mathrm{n}$.

39 Por. tamże, s. 129.

40 Por. tamże, s. 127.

${ }^{41}$ Por. C. Löhmer, R. Standhardt, TZI-Die Kunst, sich selbst und eine Gruppe zu leiten.
} Einführung in die Themenzentrierte Interaktion, Stuttgart 2006, s. 75.

42 R. C. Cohn zwraca uwagę na to, że pojęcie ,partizipativer Leitungsstil” pochodzi z terapii przeżyciowej, w której terapeuta kieruje grupąjako jej partycypujący członek, wnosząc zarazem swoją kompetencję fachową i rzeczową. Zob. P. Matzdorf, R. C. Cohn, dz. cyt., s. 48 . 
Pojęcie uczestniczącego lidera ma związek z zasadą chairperson i aksjomatem mówiącym o „autonomii i współzależności”. Zdaniem Paula Matzdorfa pojęcie „partycypacji”, w znaczeniu udziału, współuczestnictwa, przecina się z pojęciem „współzależności”“33. W zaangażowanym współudziale lider jest wzorem dla innych członków grupy, „,modelowym uczestnikiem”"44, który w swojej autentyczności jest rozumiany jako człowiek świadom własnych nastrojów i uczuć. Z selektywną otwartością ustala on kryteria dla innych, które osoby tworzące grupę podejmują jako wymagania ${ }^{45}$. Pełnienie owej funkcji polega na tym, że lider nie może wymagać od uczestników otwartości, na którą sam nie jest gotowy. Jeśli jednak nauczyciel wnosi w proces grupowy swoje własne uczucia i myśli, nie tylko pozytywne i przyjemne, to dodaje innym odwagi, by także zaangażować się wraz ze swymi cieniami i słabościami.

\subsection{Nauczyciel jako nauczyciel-uczeń i uczeń jako uczeń-nauczyciel}

Partycypujący styl kierowania świadomie urzeczywistnia fundamentalną zasadę procesu nauczania i uczenia się, do którego zdolny jest każdy człowiek. Mówi ona, że nasze życie jest bytowaniem w relacji. To właśnie należy uznawać i uwzględniać w życiu i w komunikacji wzajemnej. W tym sensie partycypujący styl kierowania jest odkrywaniem wspólnoty i solidarności między nauczycielem a uczniami ${ }^{46}$.

Temu odkryciu wspólnotowości można zaprzeczać i może być wypierane przez egocentryzm. Dlatego właśnie wychowanie powinno być zorientowane na przeciwdziałanie odpychaniu innych osób i świadome dążenie do partycypacji. Bowiem osobowość, godność i wolność nie wyrastają z abstrahowania i unikania więzi interpersonalnych, gdyż tylko w nich są możliwe. Są to formy autonomii integralnej we wprowadzaniu w życie partycypacji ${ }^{47}$.

Cohn uważa, że w środowisku szkolnym partycypującą postawę lidera rozwija wspólna troska o temat, wykazywana przez nauczycieli, którzy są tu zarazem nauczycielami i uczniami, oraz uczniów, którzy są także w pewnej mierze nauczycielami ${ }^{48}$. Paulo Freire wyraża to w następujący sposób: „Przez

${ }^{43}$ P. Matzdorf, Das TZI-Haus. Zur praxisnahen Grundlegung eines pädagogischen Handlungssystems, w: R. C. Cohn, Ch. Terfurth, Lebendiges Lehren und Lernen. TZI macht Schule, Stuttgart 1993, s. 364.

${ }^{44}$ B. Langmaack, dz. cyt., s. 126.

${ }^{45}$ Por. tamże, s. 126.

46 Por. P. Matzdorf, dz. cyt., s. 364.

47 Tamże, s. 364.

${ }^{48}$ Por. R. C. Cohn, Von der Psychoanalyse, s. 170. 
dialog w środowisku szkolnym [...] wyłaniają się nowe pojęcia: nauczycieluczeń i uczeń-nauczyciel. Nauczyciel nie jest tylko tym, który naucza, lecz kimś, kto sam jest pouczany w dialogu z uczniami, którzy, podczas gdy są pouczani, także uczą. Tak stają się oni wzajemnie odpowiedzialni za proces, w którym wszyscy wzrastają"49.

Nie znaczy to jednak, że w klasie szkolnej nie ma różnic i wszyscy są tacy sami. Należałoby to rozumieć raczej tak, że każda osoba ze swymi ograniczeniami i możliwościami może nauczać i uczyć się. Partycypacja nie zakłada więc rezygnacji z autorytetu - nauczający i uczący się posiadają go w specyficzny dla siebie sposób - ale pomaga w redukowaniu jednostronnego braku równowagi lub nie dopuszcza do jego powstawania ${ }^{50}$. Nauczyciel więc, podobnie jak uczniowie, jest uczestnikiem, a jednocześnie zachowuje postawę szacunku wobec godności każdej poszczególnej osoby w grupie, jej interakcji i realizacji zadań ${ }^{51}$.

\subsection{Kompetencje nauczyciela lidera}

Funkcja kierownicza w rozumieniu TZI nie powinna być wiązana ze statusem lub pozycja, lecz z kompetencjami. Zatem nauczyciel może przewodniczenie klasie szkolnej w określonych sytuacjach podczas realizacji pewnych tematów przekazać uczniowi, gdy ten wykazuje znajomość jakiegoś zagadnienia, lub komuś spoza grupy, kto jako ekspert może objąć czasowo kierownictwo ${ }^{52}$. W ten sposób rozumienie liderstwa TZI ma charakter klasycznie demokratyczny. Dąży ono do uchylenia hierarchicznych pozycji kierowniczych na rzecz rozwiązań funkcjonalnych, przez co zmierza od redukcji ról i struktur autorytarnych w kierunku struktur antyautorytarnych, które umożliwiają na przykład poszukiwanie prawdziwego konsensu. Lider uwzględnia w grupie zarówno zdanie mniejszości, jak i większości, ponieważ większość nie posiada monopolu na dobre idee, mniejszość ma też do nich prawo. Głosowanie według zasady ,albo-albo” (większość decyduje i ma rację) warto także tu zastąpić przez: „nie tylko, lecz także”.

Kompetencje lidera owocują różnymi subkompetencjami: kompetencjami osobowymi, społecznymi, zawodowymi i kompetencjami pola oraz ich zrównoważonym współbrzmieniem w osobie nauczyciela. Paul Matzdorf

${ }^{49}$ P. Freire, Pädagogik der Unterdrückten. Bildung als Praxis der Freiheit, Hamburg 1973, s. 64-65.

${ }^{50}$ Por. P. Matzdorf, dz. cyt., s. 365.

${ }^{51}$ Por. P. Matzdorf, R. C. Cohn, dz. cyt., s. 84.

${ }^{52}$ Warto wprowadzać to podczas spotkań z rodzicami. 
nazywa je „kompetencjami metodycznymi” w szerokim sensie ${ }^{53}$. Rozumie on przez to „sposób, w jaki indywiduum, jako istota integralna, odczuwając, postrzegając, rozeznając, oceniając i działając, podchodzi do ludzi i do świata. W tym szerokim sensie kompetencje metodyczne stanowią ogólną podstawową umiejętność człowieka, który się rozwija i kształtuje różne obszary swoich kompetencji" ${ }^{54}$.

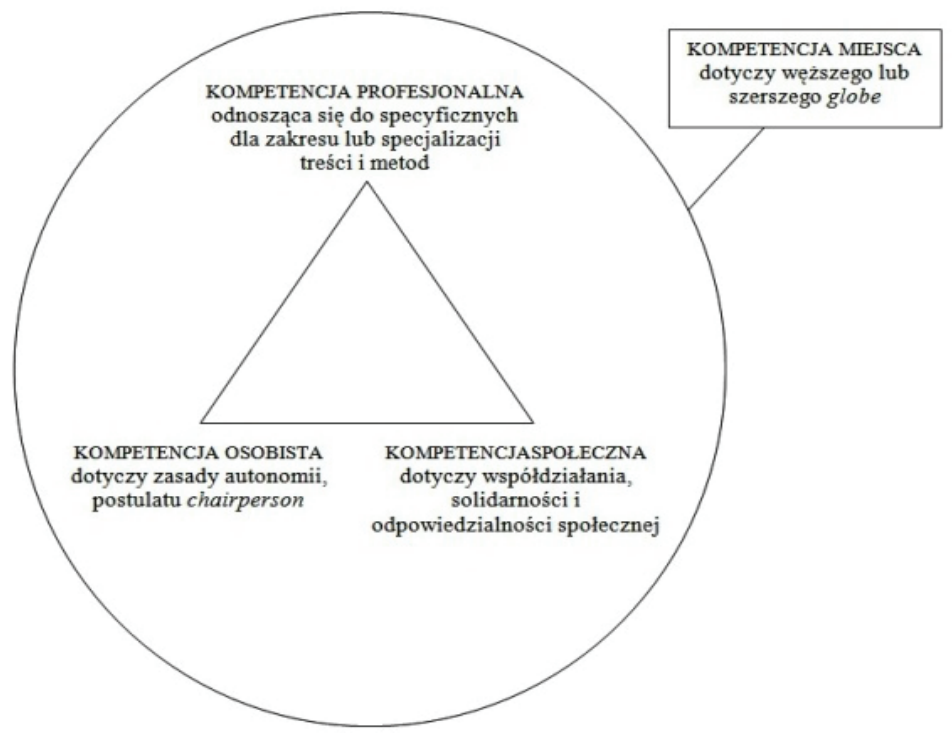

Rys. Kompetencje nauczyciela partycypującego lidera

Kompetencje wymieniane przez Matzdorfa przecinają się treściowo z tak zwanymi klasyfikacjami kluczowymi (Schlüsselqualifikationen). Są to uzdolnienia, które umożliwiają elastyczne reakcje na nowe, częściowo nieprzewidywalne wymogi życia. Oto trzy kompetencje, które wraz z kompetencją działania jako kwalifikacją i motywacją całościową określają:

- kompetencje fachowe/przedmiotowe,

- kompetencje metodyczne, na przykład metody uczenia się i pracy, metody zdobywania informacji i ich oceniania,

- kompetencje osobiste i społeczne, na przykład zdolność do kooperacji i komunikacji.

${ }^{53}$ Por. P. Matzdorf, dz. cyt., s. 378.

${ }^{54}$ Tamże, s. 380. 


\section{Przewodnictwo TZI a rola nauczyciela}

Nauczyciele w pedagogicznej odpowiedzialności realizują misję wychowywania i kształcenia. Zadanie nauczania, inspirowania uczniów do rozwijania zdolności i umiejętności wypełniają oni na podstawie solidnych kompetencji zawodowych, wyrażających się w znajomości materiału i metod jego przekazywania. Te fachowe kompetencje rozwijają się w gotowości do stałej dalszej pracy nad kształceniem osobistym, a przy tym do wykraczania poza granice własnej specjalizacji. Istotnymi cechami dobrej i skutecznej pracy nauczycieli jest gotowość do współdziałania ze wszystkimi zaangażowanymi w wychowanie i kształcenie, jak i umiejętność obudzenia w uczniach zainteresowania treściami i metodami przedmiotów szkolnych. Centralne znaczenie ma tu dbałość o wzbogacanie wiedzy i poszerzanie umiejętności wszystkich uczniów. Nauczyciel nie może traktować rozdzielnie wychowania i nauczania. Oddziaływanie wychowawcze nie ogranicza się tu do słów. Jest ono bowiem procesem złożonym, którego istotnym wyrazem jest raczej osobisty przykład. Aby być wiarygodnym nauczycielem, należy rozwijać te własne postawy, które są celem kształcenia i wychowania uczniów. W taki sposób nauczyciele pomagają młodym w poszukiwaniu orientacji życiowej, a także w staraniu o budowanie i zachowanie własnej tożsamości. Nauczyciele, którzy wychowują do postawy prospołecznej, świadomej odpowiedzialności i dojrzałości duchowej, sami muszą odznaczać się empatią, cierpliwością, zainteresowaniem i dynamiką umysłu, świadomym dążeniem do celu, bezstronnością, wolnością od uprzedzeń, równowagą emocjonalną i optymizmem, który daje siłę do osiagnięć.

W powyższym określeniu roli nauczyciela położono akcent na rozumienie kompetencji lidera wynikające z koncepcji interakcji skoncentrowanej na temacie (TZI $)^{55}$. Opisana tu postawa nauczyciela i kierownictwo w rozumieniu TZI zgodne są co do tego, że pedagog poprzez swoje umiejętności metodyczne dąży do zainspirowania uczniów do rozwoju różnych obszarów kompetencyjnych. Dzięki osobie nauczyciela na tej drodze możliwa jest integracja kompetencji specjalistycznych ze strukturą osobową i sytuacyjna, tak jak to rozumie TZI. Tylko wtedy, gdy nauczyciel w swojej osobie dokona połączenia faktorów merytorycznych i osobowych, w pracy z uczniami może inicjować integralne sytuacje uczenia się.

Należy tu podkreślić, że w ścisłym sensie TZI nie da się „stosować”, bowiem bez własnej drogi samokształcenia i wzrastania na różnych pozio-

55 Por. model P. Matzdorfa. 
mach nie nastąpi integracja ${ }^{56}$. Jeśli w ten sposób jest akcentowany moment integralny, to można te różne kompetencje (zawodowe, metodyczne, osobowe i kompetencje pola) rozumieć jako „wymiary kompetencji lidera” ${ }^{57}$ lub roli nauczyciela.

Dla R.C. Cohn jest ważne, aby nauczyciele-liderzy grup systematycznie pracowali nad rozwojem własnej osobowości i rozszerzali swoje horyzonty. Do tego zalicza ona oprócz wiedzy specjalistycznej i umiejętności metodycznych, jak na przykład odgrywanie ról, ćwiczenia medytacyjne, werbalne i niewerbalne możliwości wyrażania, techniki komunikacyjne, elementy gestalt-pedagogiczne i gestalt-terapeutyczne, także ćwiczenia ruchowe i odprężające oraz elementy terapii muzycznej ${ }^{58}$. Liderów uważa ona za współpracowników, którzy angażują się na rzecz wspólnoty i we wspólnocie. W znacznej mierze chodzi jej o takie wyuczenie się sztuki ,„postrzegania i przeżywania samodzielności i wspólnotowości, żeby stanowiły jakby dwie strony monety" ${ }^{\prime \prime}$.

Czy jednak można sobie realistycznie wyobrazić taką szkołę, takie rozumienie roli nauczyciela i ucznia? W każdym razie nauczyciele uprawiający „strategię małych kroków" 60 proponowaną przez Cohn podejmują wysiłek podążania w kierunku uczenia, które respektowało będzie coraz bardziej godność tak ucznia, jak i nauczyciela.

\subsection{Struktura, proces i zaufanie dydaktyczno-metodyczną zasadą TZI}

Trzy pojęcia: struktura, proces i zaufanie, stanowią trzy filary pracy grupowej TZI. Należy je uwzględniać jako faktory skuteczne w każdej grupie. To, co rozgrywa się w jakiejś grupie, zależy istotnie od zaufania, jakie członkowie grupy mają lub nie mają wzajemnie do siebie. Ten stosunek zaufania lub jego braku rzutuje długofalowo na proces, który wpływa na jakość relacji między uczniami w klasie.

Wzajemne oddziaływanie interpersonalne w zespole zostaje zainicjowane przez już podaną strukturę, która wpływa na aktywność grupy. Do tego przede wszystkim należy temat jako wspólna sprawa. Z punktu widzenia uczniów temat jest najczęściej uprzednio wyznaczany, ale nieczęsto w szko-

56 Por. P. Matzdorf, dz. cyt., s. 380.

57 Tamże, s. 380.

58 Por. P. Matzdorf, R. C. Cohn, dz. cyt., s. 85n.

59 Tamże, s. 151.

60 ,TZI war für mich von Anfang an der Ausdruck einer Idee, dass es doch so etwas geben müsse, was wir mitten im Grauen der Welt tun könnten, ihm etwas entgegenzusetzen, kleine Schritte, kleine winzige Richtungsänderungen”. P. Matzdorf, R. C. Cohn, dz. cyt., s. 41. 
le jest traktowany jako wspólna kwestia i najczęściej nie pokrywa się z tym, co w danym momencie ważne jest dla młodzieży. Następnie, do struktury zaliczają się wszystkie formy organizacji i zachowania społeczne, techniki pracy, metody i media, które dynamizują procesy grupowe i pracy, zachowują je i sterują nimi.

Te trzy faktory: struktura, proces i zaufanie, należy rozpatrywać jako równie ważne dla bycia razem i dla współpracy. Dla szkoły znaczy to, że nauka powinna być dobrze zaplanowana i zorganizowana. Rozwija się ona jednak dopiero w konkretnym procesie nauczania. Uczniowie zaś akceptują struktury wtedy, gdy widzą ich konieczność i pomocność w procesie uczenia się.

Dla nauczyciela jest to szczególnie ważne, by potrafił zachować odpowiednią równowagę między trzymaniem się struktury (planu) a dopuszczaniem spontanicznych pomysłów i otwarciem na kreatywność. Strukturyzacja TZI oznacza według Cohn, że proces kształcenia należy „zaplanować wcześniej ze wszystkimi znanymi elementami i prawdopodobieństwami i być otwartym na postrzeganie procesu tu-i-teraz, aby móc podjać konieczne przestawienia. Zarówno sztywne planowanie, jak i brak planowania są w równej mierze nieprzydatne" ${ }^{1}$. Także tutaj należy starać się o zachowanie dynamicznej równowagi, to znaczy nie planować ani za dużo, ani za mało oraz zachować elastyczność.

Cohn wyjaśnia, że wiele niepowodzeń w pracy grupowej TZI, także szkolnej, powstaje z braku poddawania dostatecznej refleksji struktur procesu grupowego. $Z$ powodu wad strukturalnych osłabia się proces kształcenia i zaufanie ${ }^{62}$. Współdziałanie struktury, procesu i zaufania jest podstawowym fenomenem dydaktyczno-metodycznym i bardzo znaczącym szczególnie dla planowania i realizacji nauczania i uczenia się. Właśnie dlatego P. Matzdorf uważa ,strukturę, proces i zaufanie za centralną zasadę organizacyjną szkolnego nauczania i uczenia się"63.

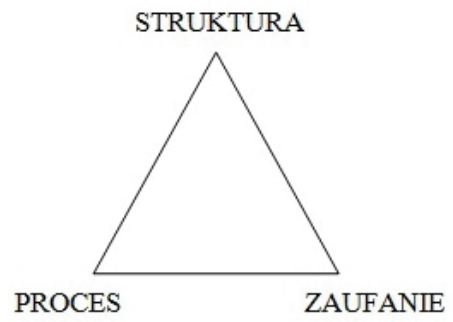

${ }^{61}$ R. C. Cohn, Von der Psychoanalyse, s. 206.

${ }_{62}$ Por. R. C. Cohn, A. Farau, dz. cyt., s. 369.

${ }^{63}$ P. Matzdorf, dz. cyt., s. 384. 


\subsection{Recepcja pedeutologiczna}

\section{Partycypujące kierowanie jako wymaganie pedagogiczne}

TZI zwraca szczególną uwagę na kierowanie procesami grupowymi, które jest priorytetowo aktualne w środowisku szkolnym. Koncepcja ta różni się z jednej strony od wszystkich form działań pedagogicznych pozbawionych przewodnictwa zespołów lub tylko moderowanych, a z drugiej strony od programów nauczania związanych wyłącznie z metodami i środkami. Specyficzna dla kierownictwa grupowego w TZI jest zachęta do otwartego uczenia się i komunikowania. Osoby kierujące grupami w TZI angażują się wraz z uczestnikami w każdorazowy proces interakcji grupowej. Uczestniczą aktywnie i świadomie w procesach, które same prowadzą.

O kierowaniu uczestniczącym w grupach TZI można mówić wtedy, gdy nauczyciel porusza się na granicy między egzystencjalnym zaangażowaniem $\mathrm{w}$ tematy i procesy grupowe a równocześnie jasno postrzeganą swoją funkcją kierownicza, rozumianą nie jako status, lecz jako zaangażowanie na rzecz grupy. Kierowanie uczestniczące według TZI wymaga długiego ćwiczenia i, jeśli to możliwe, profesjonalnego wykształcenia ${ }^{64}$. Zadaniem kierownika grupy jest między innymi czuwanie nad „dynamiczną równowagą” wszystkich faktorów, które ciagle znajdują zastosowanie w żywych procesach grupowych i łączą się ze sobą.

\section{Chairpersonship jako pedagogiczna zdolność oceny}

Jeden z postulatów TZI brzmi: Be your own chairperson. Przewodniczenie (chairpersonship) odnosi się do selektywnej autentyczności ${ }^{65}$ każdej poszczególnej osoby i postrzegania jej odpowiedzialności wśród mnóstwa możliwości, różnorodnych głosów we własnym wnętrzu, za którymi może człowiek podążać lub nie. Przewodnictwo to oznacza świadome postrzega-

${ }^{64}$ Ruth Cohn Institute for TCI-International oferuje w dalszym ciagu w wielu krajach Europy i Ameryki kształcenie w kierunku żywego uczenia. Ponadto wiele propozycji kształcenia $z$ instytutów regionalnych i grup specjalistycznych.

${ }^{65}$ Wyrażenie „selektywna autentyczność” wywodzi się języka specjalistycznego TZI i oznacza, że ludzie (w różnych sytuacjach i kontekstach, w jakich są postawieni) ukazują się autentycznymi (a więc nie udają niczego, lecz są prawdziwi). Mogą oni równocześnie selektywnie decydować, w jakim stopniu w konkretnej sytuacji chcą ujawnić coś z siebie. W świadomej decyzji, ile i jakiego rodzaju selektywność lub otwartość jest przewidziana, ukazuje się aspekt zasady chairperson. 
nie istniejących możliwości i podjęcie decyzji. Pedagogika komunikacyjna przejmuje z TZI postulat przewodnictwa, by nie redukować pedagogiki do teoretycznego rozumienia niezależnego od osoby, lecz zarówno jej powstanie, jak i przekaz łączy z konkretnymi ludźmi, którzy postępują mniej lub bardziej autentycznie i odpowiedzialnie.

Pojęcie przewodnictwa Cohn jest zorientowane na wyobrażenie wewnętrznej grupy z jej różnorodnymi dążeniami, które istnieją w człowieku w każdym momencie jego życia. Bycie chairperson zakłada z jednej strony świadomą rezygnację z wypierania tych dążeń, a z drugiej zachowanie równowagi, tak by się wzajemnie nie przysłaniały. Uaktywnione chairpersonship czyni człowieka zdolnym - we wrażliwej czujności skierowanej tak do wnętrza, jak i na zewnątrz - do podejmowania jasnych decyzji. Nie są one ani bezbłędne, ani niemożliwe do poprawienia, ale pomagają w danym momencie realizować tę przestrzeń wolności człowieka, która znajduje się między fantazją niemocy (nie móc nic uczynić) i fantazją wszechmocy (wszystko móc zmienić), stanowiąc rzeczywistą przestrzeń działania.

\section{Pierwszeństwo przeszkód jako wyzwanie pedagogiczne TZI}

Disturbances and passionate involvements take precedence stwierdza Cohn w postulacie o priorytecie problemów i tego, co nieoczekiwane. One przejmują pierwszeństwo w procesach ludzkiej komunikacji, nie pytając o pozwolenie. Obok znaczenia nadawanej wytrzymałości dla wzrastania człowieka, co Cohn przejęła z psychoanalizy, także priorytet zakłóceń może odpowiednio zintegrować czynniki konfliktowe, tak w poszczególnym człowieku, jak i w relacjach międzyludzkich.

Partycypujące przewodniczenie nauczyciela, jego świadome skoncentrowanie na temacie oraz strukturyzacja procesów edukacyjnych, wychodząca od tematu, umożliwiają jasną orientację w procesach pedagogicznych.

Wymienione tu czynniki nie mogą jednak stać się gorsetem, który zasadniczą otwartość i niemożność definitywnego zamknięcia pracy pedagogicznej ogranicza lub czyni zupełnie niemożliwą. W ten sposób poddaje się badaniom nie tylko rezultaty kształcenia człowieka, lecz także jego samego w sytuacjach powodzenia i niepowodzenia. Powstaje więc żywa dynamika, która dla wszystkich uczestników procesu kształcenia stanowi jakieś szczególne wyzwanie. Z tym wymaganiem wobec uczestniczących w procesach pedagogicznych łączy się zasada chairperson. 


\section{Zakończenie}

Na bazie partycypującego liderstwa TZI rozwija się pedagogiczna kultura komunikacji. W czasach, gdy praca badawcza i kształcenie nastawione są nierzadko na szybki sukces, pedagogika rozwijana na bazie TZI angażuje się w umacnianie kultury otwartej na spowolnienie ${ }^{66}$, promującej życie, wspierającej postawę budowania pokoju i harmonijnego rozwoju. Wyraża się to w staraniu o zdobycie kompetencji, które są zaniedbywane w wielu aktualnych projektach badawczych i edukacyjnych. TZI uwrażliwia bowiem między innymi na jakość procesów edukacyjnych, a także na tematy i wydarzenia usuwane w cień.

Ważnym założeniem pedagogiki rozwijanej na bazie TZI jest wspieranie zdolności do postrzegania zarówno z własnej perspektywy, jak i z punktu widzenia innych osób, oraz dążenie do zrozumienia drugiego człowieka. Ona bowiem uzdalnia do dojrzałego traktowania różnic między własną i obcą perspektywą, rozwija umiejętność wyjaśniania, nakreślania czy poszerzania perspektyw.

Proces partycypującego kierowania w pedagogice szkolnej TZI jest otwarty, a jego wyników nie da się z góry przewidzieć. Nie oznacza to jednak zupełnej dowolności; istnieją już kontury, istnieją opisy drogi, ale bez uprzedzania? Tak więc nauczyciel będący uczestniczącym liderem szanuje godność osób, które spotyka w procesie dydaktyczno-wychowawczym. Rezygnacja z uprzedniego lub pryncypialnego wykluczania pewnych pytań należy do jego postawy.

Pedagogika komunikacyjna jest quasi-rozszerzeniem wszechświata (expanding universe), co umożliwia także kierowanie się dynamiką pytań otwartych. Pytania otwarte mają bowiem prowokacyjny charakter. Wzywają one w edukacji do coraz większej otwartości i do poszerzenia horyzontów komunikacji w living learning, rozwijanym przez liczne ośrodki kształcenia w Europie Zachodniej i Ameryce.

Kontynuowane aktualnie badania nad TZI według R.C. Cohn i rozwijany warsztat wprowadzania jej w środowisko szkolne wskazują, że zarysowany w artykule model żywego uczenia jest ważnym impulsem dla rozwoju szkolnej pedagogiki komunikacji. Living learning stanowi zatem również

${ }^{66}$ Por. F. Reheis, Entschleunigung. Abschied vom Turbokapitalismus, München 2006; S. Brembeck, „Nicht die Zeit macht uns fertig, sondern das Tempo”. Die Kunst als retardierendes Element im Religionsunterricht, „Religionspädagogische Beiträge” 44 (2000), s. 109-119. 
wyzwanie dla pedeutologii, która może zainspirować się rozwojem idei nauczyciela-partycypującego lidera.

\section{Teacher as a Participative Leader. Participative Leadership in Ruth C. Cohn's Theme-Centred Interaction (TCI) (Summary)}

In the Theme-Centred Interaction, special attention is given to the management of group processes, which are present in the school environment. TCI differs not only from all forms of educational activities that are devoid of group leadership, or merely moderated, but also from the learning programs with predetermined methods and media. What is specific for group leadership within TCI is the encouragement to learn and communicate. The teachers who lead a group of students according to TCI are expected to get involved in the group interaction process together with the students. They consciously and actively take part in the processes that they direct. Participative leadership also means that in the course of directing a group, leaders reveal their opinions and viewpoints.

Participative leadership in TCI groups occurs when a teacher constantly moves along the border between his existential involvement in the subject and the group processes, but at the same time he clearly understands his own function of a leader, which is understood not as a status but as a commitment to the group. Participative leadership according to TCI requires long practice and, if possible, professional training. The task of a group leader, amongst others, is to watch over "the dynamic equilibrium" (dynamische Balance in German) between all the factors that are still used in live group processes and that join one another. Participative leadership on the methodical and scientific level opens up the way for investigation of participation, which should be further developed. 